\title{
Prevalence and Fluconazole Susceptibility Profile of Candida spp. Clinical Isolates in a Brazilian Tertiary Hospital in Minas Gerais, Brazil
}

\author{
ATHAYDE NEVES-JUNIOR ${ }^{1 *}$, ANA CAROLINA CARTÁGENES-PINTO ${ }^{1 *}$, DÉBORA A.S. ROCHA ${ }^{1 *}$, \\ LEANDRO F. REIS DE SÁ ${ }^{1 *}$, MARIA DE LOURDES JUNQUEIRA ${ }^{2}$ and ANTONIO FERREIRA-PEREIRA ${ }^{1}$ \\ ${ }^{1}$ Laboratório de Bioquímica Microbiana, Instituto de Microbiologia Paulo de Góes, \\ Universidade Federal do Rio de Janeiro, Av. Carlos Chagas Filho, 373, Bloco I, \\ Sala 44, Ilha do Fundão, 21949-902 Rio de Janeiro, RJ, Brasil \\ ${ }^{2}$ Hospital Universitário, Universidade Federal de Juiz de Fora, \\ Rua Catulo Breviglieri, s/n, Bairro Santa Catarina, 36036-110 Juiz de Fora, MG, Brasil \\ Manuscript received on December 22, 2014; accepted for publication on March 3, 2015
}

\begin{abstract}
Candidiasis has become an important concern for clinical practice, especially with the increasing incidence of immunocompromised patients. In this scenario, the development resistance to fluconazole presents a challenge for treating these opportunistic infections. The aim of this study was to evaluate some epidemiology features of Candida infections in a Brazilian University Hospital using data, previously unavailable. We observed that $44 \%$ of the 93 clinical isolates tested, belonged to Candida albicans species and $56 \%$ belonged to non-Candida albicans species (mainly Candida tropicalis and Candida glabrata). Most strains were isolated from urine samples where C. albicans was predominantly detected. 29 strains presented a fluconazole resistance phenotype and of these, 22 were chemosensitised by FK506, a classical inhibitor of $\mathrm{ABC}$ transporters related to azoles resistance. These data suggest the probable role of efflux pumps in this resistance phenotype. Our study highlights the need for developing effective control measures for fungal infections, rational use of antifungal drugs and development of new molecules able to abrogate the active transport of antifungals.
\end{abstract}

Key words: Candida spp., clinical isolates, epidemiology, fluconazole, resistance.

\section{INTRODUCTION}

Candida spp. infections are recognized as a major challenge in public health, commonly associated with high morbidity and mortality since its diagnosis and treatment present difficulties and high healthcare costs (Colombo et al. 2008, Gudlaugsson et al. 2003, Arnold et al. 2010). In

Correspondence to: Antonio Ferreira Pereira

E-mail: apereira@micro.ufrj.br

${ }^{*}$ These authors contributed equally
Latin America, mortality rates are usually higher than those observed in the Northern Hemisphere; however, it is worth mentioning that epidemiology of candidemia is poorly studied in this region in comparison to the United States and Europe (Nucci et al. 2013, Colombo et al. 2008, Santolaya et al. 2014).

In Brazil, studies demonstrated that incidence rates of Candida infections are heterogeneous in different regions (Colombo et al. 2006, Nucci et al. 2010). There are several studies that focus 
specifically on the Southeast (Colombo et al. 1999, 2006, Costa et al. 2000, Resende et al. 2002, de Resende et al. 2006, Aleva et al. 2007, Ribeiro et al. 2010, Oliveira et al. 2014, Moretti et al. 2013), Midwest (Leite Junior et al. 2011, HoffmannSantos et al. 2013, Akeme Yamamoto et al. 2012), North-east (Mascarenhas et al. 2012, Araujo Paulo de Medeiros et al. 2014, Nascimento Mdo et al. 2014) and South of Brazil (Antunes et al. 2004, Pasqualotto et al. 2008, da Costa et al. 2014).

Fluconazole (FCZ) is the first option for prophylaxis and treatment, due to its good tolerance, few side effects and low costs ( $\mathrm{Li}$ et al. 2014). However, the widespread and prolonged use of antifungal agents induces tolerance development as well as collateral resistance to other drugs (Prasad and Rawal 2014). Some species, such as Candida glabrata and Candida krusei, already present decreased susceptibility or resistance to FCZ (Wingard et al. 1991, Marr et al. 2000). Preventing the intracellular accumulation of a drug by rapid extrusion of the antifungal agent is a known mechanism of resistance (Prasad et al. 2002). The overexpression of efflux pumps, such as ATP-binding cassette (ABC) family or major facilitator superfamily (MFS), has been shown to be the cause of resistance in some fungi (Cannon et al. 2009).

The aim of this study is to evaluate the frequency of yeast species isolated from urine, faeces, catheter, blood and other secretions, analyze the susceptibility to FCZ as well as investigate the possible mechanism of resistance of clinical strains obtained from the University Hospital of the Federal University of Juiz de Fora, Minas Gerais, Brazil, over a period of two years (2012-2014).

\section{MATERIALS AND METHODS}

\section{YEAST STRAINS AND PATIENTS}

Ninety-three Candida spp. isolates were obtained from patients at the University Hospital of Universidade Federal de Juiz de Fora, Minas Gerais,
Brazil, during the period of 2012 to 2014. Isolates were collected from different clinical material: urine, faeces, catheter, blood and other secretions, from patients treated in ICU and/or ambulatory units. Candida ATCC strains were used as control for species identification: C. albicans 10231, C. tropicalis 750, C. parapsilosis 90018, C. glabrata 2001, C. krusei 34135, C. dubliniensis MYA-646, C. guilliermondii 7350. This project was approved by Instituto de Estudos em Saúde Coletiva - IESC/ UFRJ - Protocol No 030/2001.

\section{Cell Growth AND Culture Conditions}

The yeast strains grown in YPD medium $(2 \%$ glucose, $2 \%$ peptone, $1 \%$ yeast extract) at $37{ }^{\circ} \mathrm{C}$ under agitation, were harvested in the exponential phase of growth and stored at $4{ }^{\circ} \mathrm{C}$.

\section{STRAIN IDENTIFICATION}

Isolate identification was performed by MALDI Microflex LT (Bruker Daltonics, Bremen, Germany) measurement, according to manufacturer formic acid extraction procedure. Briefly, in this identification method, a single colony of each strain grown overnight on YPD agar was suspended in $300 \mu \mathrm{L}$ of de-ionized water and $900 \mu \mathrm{L}$ of absolute ethanol and centrifuged at 14,462 $\mathrm{xg}$ for $2 \mathrm{~min}$. The supernatant was discarded and the pellet was airdried. $1: 1 \vee 70 \%$ formic acid and 100\% acetonitrile were added to the pellet and vortexed. The samples were centrifuged at $14,462 \mathrm{xg}$ for $2 \mathrm{~min}$, and $1 \mu \mathrm{Lof}$ the supernatant was spotted in duplicate onto a steel target and air-dried at room temperature. Before identification, each spot was overlaid with $1 \mu \mathrm{L}$ of HCCA ( $\alpha$-Cyano-4-hydroxycinnamic acid, Bruker) matrix solution saturated with organic solvent $(50 \%$ acetonitrile and $2.5 \%$ trifluoroacetic acid) and air dried completely. The spectra were externally calibrated using standard ATCC Escherichia coli 25922, before plate identification. Raw spectra were processed using MALDI BIOTYPER Realtime Classification software version 3.1 (Bruker Daltonik MALDI Biotyper). Strains with 
score values $\geq 2$ were indicated as reliable species identification.

\section{ANTIFUNGAL SUSCEPTIBILITY TESTS}

In vitro susceptibility tests were performed using the broth microdiluition assay according to the protocol of the Clinical and Laboratory Standards Institute (CLSI) M27-A2 protocol. According to CLSI, FCZ $\mathrm{MIC}_{50}$ (Minimal Inhibitory Concentration) end points $\leq 8 \mu \mathrm{g} / \mathrm{mL}$ were categorized as susceptible. $\mathrm{MIC}_{50}$ end points between 16 and $32 \mu \mathrm{g} / \mathrm{mL}$ were classified as susceptible dose-dependent (SDD), and resistant strains obtained $\mathrm{MIC}_{50}$ end points $\geq$ $64 \mu \mathrm{g} / \mathrm{mL}$. Cell growth was analyzed in a microplate reader at $600 \mathrm{~nm}$ (Fluostar Optima, BMG Labtech, Offenburg, Germany).

EVALUATION OF FLUCONAZOLE

RESISTANCE REVERSION BY FK506

Since FK506 is a classical ABC transporter inhibitor (Egner et al. 2000), it was used as an identifier for resistance mediated by these transporters. The "spot test" was used as a measure of growth as previously described by (Reis de Sa et al. 2014).

TABLE I

Number (n) and percent (\%) of strains collected from different clinical sources. The isolates were collected mainly in urine samples.

\begin{tabular}{ccc}
\hline Clinical sources & $\begin{array}{c}\text { Number of } \\
\text { strains (n) }\end{array}$ & $\begin{array}{c}\text { Percent } \\
(\mathbf{\%})\end{array}$ \\
\hline Urine & 71 & 76.3 \\
\hline Blood & 8 & 8.6 \\
\hline Catheter & 5 & 5.4 \\
\hline Tracheal secretion & 4 & 4.3 \\
\hline Ascitic fluid & 2 & 2.2 \\
\hline Faeces & 1 & 1.1 \\
\hline Abdominal secretions & 1 & 1.1 \\
\hline Gastrostomy secretion & 1 & 1.1 \\
\hline Total & 93 & 100 \\
\hline
\end{tabular}

\section{FLOW CYTOMETRY ASSAY}

The experiment was performed using eight representative resistant Candida spp. isolates. The cells were incubated overnight in $20 \mathrm{ml}$ of YPD medium $1 \times 10^{3}$ cells $/ \mathrm{mL}$ at $37{ }^{\circ} \mathrm{C}$ under agitation. After incubation, with a value of 1.0 to $3.0 \mathrm{OD}$, the cells were centrifuged (5000 x $g / 5$ min) and washed four times with deionized water. After washing, the strains were maintained on ice for $2 \mathrm{~h}$. A concentration of $6 \times 10^{5}$ cells $/ \mathrm{mL}$ were incubated with Rhodamine 6G (R6G) $(5 \mu \mathrm{M})$, an $\mathrm{ABC}$ transporter fluorescent substrate (Maesaki et al. 1999), in the presence or absence of glucose $(2 \%)$ for $1 \mathrm{~h}$, at $37{ }^{\circ} \mathrm{C}$ under agitation. The cells were centrifuged (9000 x $\mathrm{g} / 2 \mathrm{~min}$ ) and washed with PBS buffer $(3 \mathrm{X})$ before analysis in duplicate by BD Accuri' ${ }^{\mathrm{TM}} \mathrm{C} 6$ Flow Cytometer, in order to measure of R6G efflux by strains.

\section{DATA ANALYSES}

Data analysis was performed using the Statistical Package for the Social Sciences $\left(\mathrm{SPSS}^{\complement}\right)$ ) software (version 20).

\section{RESULTS}

CliniCAL SOURCE ANALYSIS AND SPECIES IDENTIFICATION

We analyzed a total of 93 Candida spp. isolates in a period of two years (2012-2014). The isolates were collected from different clinical samples as summarized in Table I. Most Candida spp. isolates were detected in urine samples $(n=71,76 \%)$. The other samples presented a fewer number of isolates: blood $(n=8,8.6 \%)$, catheter $(n=5,5.4 \%)$, tracheal secretions $(n=4,4.3 \%)$, faeces $(n=1,1.1 \%)$, ascetic fluid $(n=2,2.2 \%)$, abdominal $(n=1,1.1 \%)$ and gastrostomy secretions $(\mathrm{n}=1,1.1 \%)$.

The MALDI-TOF mass spectrometry method enabled Candida spp. strain identification in eight species: Candida albicans $(\mathrm{n}=41,44.1 \%)$, Candida tropicalis ( $\mathrm{n}=26,28 \%)$, Candida glabrata $(\mathrm{n}=14,15.1 \%)$, Candida parapsilosis $(\mathrm{n}=7,7.5 \%)$, Candida kefyr $(\mathrm{n}=2,2.2 \%)$, Candida metapsilosis 


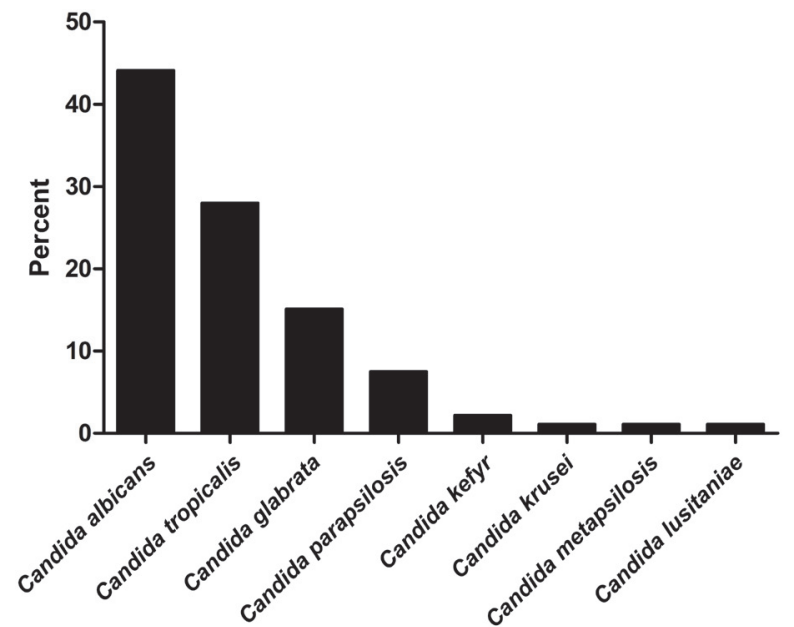

Figure 1 - Percentage of species identified by MALDI-TOF mass spectrometry. C. albicans $(44.1 \%)$, C. tropicalis $(28 \%)$, C. glabrata (15.1\%), C. parapsilosis (7.5\%), C. kefyr (2.2\%), C. krusei (1.1\%), C. metapsilosis (1.1\%), C. lusitaniae (1.1\%).

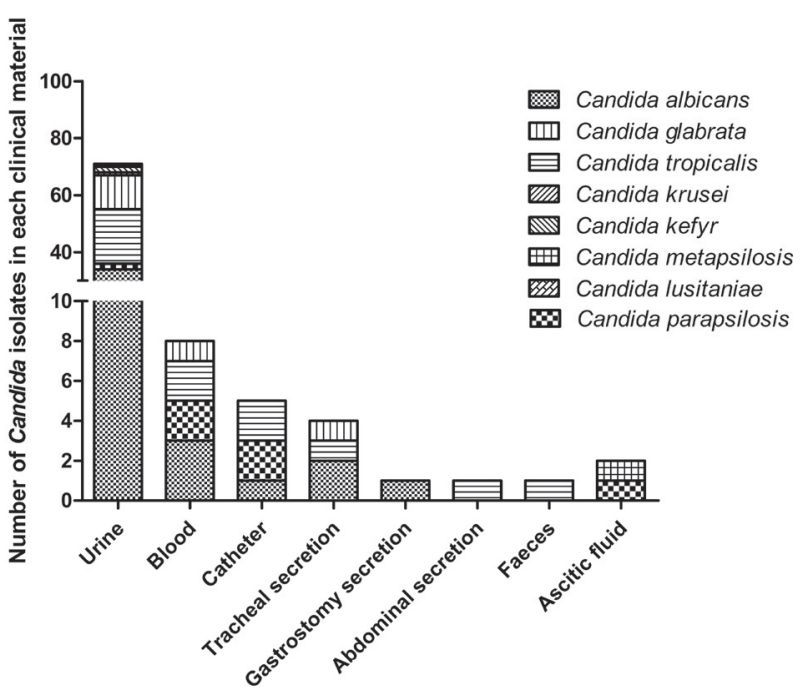

Figure 2 - Number of species Candida isolated from each clinical source. The majority of clinical isolates were $C$. albicans in urine samples.

TABLE II

Fluconazole susceptibility profile of Candida spp. isolates.

\begin{tabular}{lcccc}
\hline & (n) & Susceptible (\%) & Susceptible - dependent dose (\%) & Resistant (\%) \\
\hline Candida albicans & 41 & $27(46.6)$ & $3(50)$ & $11(38)$ \\
Candida tropicalis & 26 & $12(20.7)$ & $1(16.7)$ & $13(45)$ \\
Candida glabrata & 14 & $10(17.2)$ & $0(0)$ & $4(13.8)$ \\
Candida parapsilosis & 7 & $7(12)$ & $0(0)$ & $0(0)$ \\
Candida krusei & 1 & $0(0)$ & $0(0)$ & $1(3.4)$ \\
Candida kefyr & 2 & $1(1.7)$ & $1(16.7)$ & $0(0)$ \\
Candida metapsilosis & 1 & $1(1.7)$ & $0(0)$ & $0(0)$ \\
Candida lusitaniae & 1 & $0(0)$ & $1(16.7)$ & $0(0)$ \\
\hline Total & 93 & 58 & 6 & 29 \\
\hline
\end{tabular}

$(\mathrm{n}=1,1.1 \%)$, Candida krusei $(\mathrm{n}=1,1.1 \%)$ and Candida lusitaniae ( $\mathrm{n}=1,1.1 \%$ ) (Fig. 1).

Correlating clinical sources and species identification, $C$. albicans was the most prevalent specie in urine samples ( $\mathrm{n}=34,48 \%)$, followed by C. tropicalis $(\mathrm{n}=19,27 \%)$ and C. glabrata $(\mathrm{n}=12$, $17 \%)$. C. albicans was also prevalent in blood samples $(n=3,37.5 \%)$, gastrostomy secretion $(n=1$, $100 \%)$ and tracheal secretions $(n=2,50 \%)$ (Fig. 2).

\section{FLUCONAZOLE SUSCEPTIBILITY}

In order to classify susceptible (S), susceptible dose-dependent (SDD) and resistant strains (R), we performed a FCZ susceptibility assay. 58 isolates presented a susceptible profile $(62.5 \%)$, six were SDD $(6.5 \%)$ and 29 were selected as resistant to FCZ (31\%).

The majority of resistant strains belonged to the C. tropicalis species ( $\mathrm{n}=13,45 \%)$, while $C$. albicans 
TABLE III

Minimal inhibitory concentration $\left(\mathrm{MIC}_{50}\right)$ of resistant to FCZ Candida spp. isolates according to CLSI M27-A2 protocol.

\begin{tabular}{|c|c|c|}
\hline Code & Species & $\begin{array}{c}\mathrm{MIC}_{50} \mathrm{FCZ} \\
(\mu \mathrm{g} / \mathrm{mL})\end{array}$ \\
\hline 1002 & Candida tropicalis & $>1000$ \\
\hline 1016 & Candida albicans & $>1000$ \\
\hline 1050 & Candida tropicalis & $>1000$ \\
\hline 107 & Candida glabrata & $>1000$ \\
\hline 109 & Candida glabrata & $>1000$ \\
\hline 1114 & Candida albicans & $>1000$ \\
\hline $24 i$ & Candida tropicalis & $>1000$ \\
\hline 1027 & Candida tropicalis & $>500$ \\
\hline $154 \mathbf{i}$ & Candida albicans & $>500$ \\
\hline $224 A$ & Candida albicans & $>500$ \\
\hline $338 \mathbf{i}$ & Candida tropicalis & $>250$ \\
\hline $424 i$ & Candida tropicalis & $>250$ \\
\hline $451 A$ & Candida tropicalis & $>250$ \\
\hline $541 \mathrm{i}$ & Candida albicans & $>250$ \\
\hline $211 i$ & Candida tropicalis & $>250$ \\
\hline $330 \mathrm{i}$ & Candida tropicalis & $>125$ \\
\hline $44 i$ & Candida tropicalis & $>125$ \\
\hline $124 i$ & Candida krusei & $>64$ \\
\hline $148 \mathrm{~A}$ & Candida tropicalis & $>64$ \\
\hline $14 \mathrm{~A}$ & Candida albicans & $>64$ \\
\hline $163 A$ & Candida glabrata & $>64$ \\
\hline $218 \mathrm{i}$ & Candida glabrata & $>64$ \\
\hline $242 A$ & Candida tropicalis & $>64$ \\
\hline $250 \mathrm{i}$ & Candida albicans & $>64$ \\
\hline $25 \mathbf{i}$ & Candida tropicalis & $>64$ \\
\hline $326 A$ & Candida albicans & $>64$ \\
\hline $337 \mathbf{i}$ & Candida albicans & $>64$ \\
\hline $479 \mathrm{i}$ & Candida albicans & $>64$ \\
\hline 389A & Candida albicans & $>64$ \\
\hline
\end{tabular}

was the most prevalent susceptible $(n=27,46.6 \%)$ and SDD ( $\mathrm{n}=3,50 \%)$ isolate (Table II). The $\mathrm{MIC}_{50}$ values of each resistant strain are summarized in Table III. Seven Candida isolates presented $\mathrm{MIC}_{50}$ higher than the maximum tested concentration: three of these strains were C. tropicalis, two $C$. albicans and two C. glabrata. Three isolates were resistant to concentrations higher than $500 \mu \mathrm{g} / \mathrm{ml}$, five for $250 \mu \mathrm{g} / \mathrm{ml}$, two for $125 \mu \mathrm{g} / \mathrm{ml}$ and eleven for $64 \mu \mathrm{g} / \mathrm{ml}$.

\section{REVERSION OF FLUCONAZOLE RESISTANCE}

After the screening of clinical strains resistant to FCZ, we performed a chemosensitization assay using FK506 in order to evaluate the possible resistance mechanism of these Candida spp. isolates. The resistance phenotype of 22 clinical strains reverted upon treatment with the $\mathrm{ABC}$ transporter inhibitor, while the other seven $(1016,250 \mathrm{i}, 14 \mathrm{~A}, 163 \mathrm{~A}, 1027$, $124 \mathrm{i}, 1114$ ) isolates remained resistant, even in the presence of FK506 (Fig. 3). Among the 22 resistant Candida strains chemosentitized by FK506, we observed that 11 were $C$. tropicalis, seven were $C$. albicans, 4 C. glabrata.

\section{FLOW CYTOMETRY}

Flow cytometry assay was performed in order to check the capability to extrude Rhodamine 6G (R6G), a fluorescent substrate pumped by ABC transporters, by resistant strains. For this test, we used four representative strains reverted by FK506 (Fig. 4a) and four that remained resistant even in the presence of FK506 (Fig. 4b). The data revealed that strains reverted by FK506 were able to pump out R6G in the presence of glucose whereas strains that displayed high level of resistance to FCZ, even in the presence of FK506, were not able to efflux the fluorescent probe in the presence or absence of glucose. These results confirm those obtained by chemosensitization assay (Fig. 3) since reverted strains also presented an efflux of R6G. 


\begin{tabular}{|c|c|c|c|c|c|}
\hline CTRL & FCZ + FK506 & & CTRL & $\mathrm{FCZ}$ & FCZ + FK506 \\
\hline 10020 유 하 & 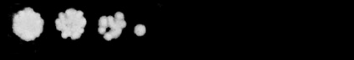 & $330 \mathrm{i}$ & 0 策 : & 畨 & \\
\hline $25 i 00$ 路 & 解 & $44 i$ & 일앙 & 0,8 & \\
\hline $107 \bigcirc$ & 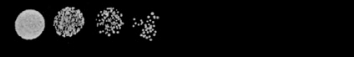 & 109 & O 辣: & O & \\
\hline $479 i$ & O tax & $154 i$ & $0=0$ & 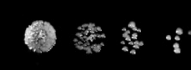 & \\
\hline 424i O숭 :- & D盛 & $211 i$ & $0 \%$ & 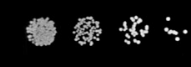 & \\
\hline 218i OOS & 00 울 & $224 \mathrm{~A}$ & 00 & OS & \\
\hline $242 \mathrm{~A} \bigcirc \mathrm{b}$ & 03 ; & $338 \mathrm{i}$ & $O D$ & 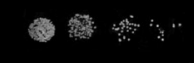 & \\
\hline $326 \mathrm{~A} \bigcirc \mathrm{O}$ & 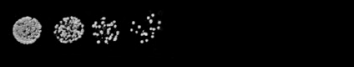 & 1050 & 당 sto & 을 & \\
\hline $337 \mathrm{i} O \mathrm{a}$ & 0 数 & 1016 & O 19 & (193. & a. \\
\hline 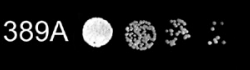 & - 19 & $250 \mathrm{i}$ & $6 x^{\circ}$ & 数 & 湾的。 \\
\hline $451 \mathrm{~A}$ 울 & a & $14 \mathrm{~A}$ & 001 & 000 at: & 00 \\
\hline 541i O & 웅 & $163 A$ & 울 중 & O 1 : & O 雪 \\
\hline $24 \mathrm{i} O \mathrm{Ca}$ & 잉 & $\cdot 1027$ & 0 웅 & 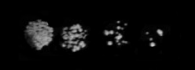 & 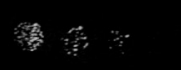 \\
\hline $148 \mathrm{~A} O$ 애 & 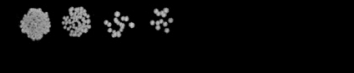 & $124 i$ & 00 a & OD致 & $00 \mathrm{~g}$ \\
\hline & & 1114 & O裳管. & 영 & 9 \\
\hline
\end{tabular}

Figure 3 - Evaluation of FCZ reversion by FK506 on 29 resistant Candida spp. clinical strains. CTRL: yeast cells growth on Sabouraud solid medium in absence of FCZ for $48 \mathrm{~h}$. FCZ (+): yeast cell growth on Sabouraud solid medium containing $64 \mu \mathrm{g} / \mathrm{mL}$ of FCZ. FCZ(+) and FK506: yeast growth in same conditions as CTRL plus FCZ $(+)$ presenting FK506 10 $\mu \mathrm{M}$. Most clinical strains presented resistance reversion using FK506, a classic ABC transporter inhibitor. Only seven strains were still resistant to $\mathrm{FCZ}$ even in the presence of the inhibitor.
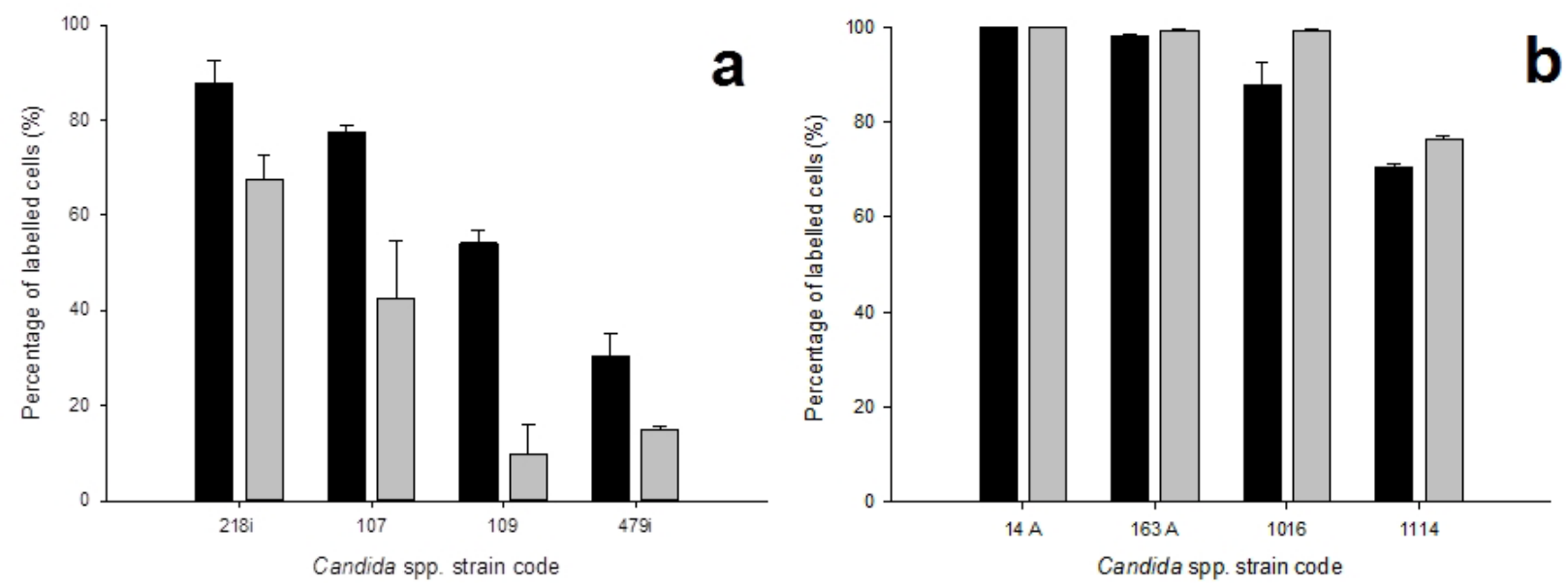

Figure 4 - Citometry efflux assay of Candida spp. strains using R6G as fluorescent substrate in the presence and absence of glucose. (a) Flow citometry conducted with clinical isolates that were chemosensitized by FK506. (b) Flow citometry assay of clinical isolates that retained resistance phenotype using FK506. Black bar = no glucose; Gray bar $=$ with glucose. This experiment represents average of triplicate. 


\section{DISCUSSION}

Regional differences in the incidence pattern of antifungal resistance and patient suceptibility can be found when monitoring fungal infections. Knowledge of the epidemiological characteristics of a certain community has both local and global importance, considering the constant flow of individuals within a country and around the world (Nucci et al. 2010). Since Candida spp. are the most common fungal nosocomial pathogens, contributing significantly to morbidity and mortality (Wisplinghoff et al. 2014, Pfaller et al. 2014), we decided to evaluate the prevalence of Candida infections at a Brazilian University Hospital located in a Southeast region, where no epidemiologic data relating to candidiasis had been previously collected. We also determined the susceptibility profile of Candida spp. strains - isolated from clinical material - as well as the possible role of $\mathrm{ABC}$ transporters in the $\mathrm{FCZ}$ resistance.

Our results revealed that the Candida species most commonly isolated were C. albicans (44.4\%), C. tropicalis (28\%) and C. glabrata (14\%) (Fig. 1). These data were consistant with other Brazilian and international studies concerning nosocomial fungal infections, which show C. albicans as the most prevalent species isolated (Wille et al. 2013, da Costa et al. 2014, Corzo-Leon et al. 2014).

Furthermore, we observed a higher proportion of non-albicans species (56\%) compared with Candida albicans (44\%), a trend which has also been observed in other studies. Oliveira and colleagues evaluated cases of fungemia from 2007 to 2010 and observed a higher prevalence of candidemia caused by Candida species other than C. albicans during a period of four years (Oliveira et al. 2014). Moretti and colleagues observed an increasing incidence of candidemia caused by $C$. tropicalis and C. glabrata between 2006 and 2010 (Moretti et al. 2013). Pfaller et al. 2014 also pointed to the emergence of invasive fungal infections caused by non-albicans species of Candida in a study comprising 23 medical centers in the United States and two in Canada (Pfaller et al. 2014).

Urinary tract infections caused by Candida spp. are commonly observed in hospitalized patients, especially those in intensive care units (Kauffman 2014). The tendency of hospitalized patients to be predisposed to urinary tract infections caused by Candida spp is explained by factors such as instrumentation of the urinary tract, prolonged hospitalization, use of broad spectrum antibiotics and indwelling urinary tract devices (Sobel et al. 2011). The evaluation of bacteriuria and candiduria in an intensive care unit (ICU), conducted by Aubron and colleagues over a period of six years (20062011), demonstrated that Candida spp. represented $55 \%$ of pathogens isolated from positive urine cultures (Aubron et al. 2015). We also observed this high Candida spp. prevalence in urinary tract infections, with 71 of the 93 isolates tested, coming from urine samples (Table I). Of these, the three most prevalent species were C. albicans (34/ 71 48\%), C. tropicalis (19/ 71 - 27\%) and C. glabrata (12/ $71-17 \%)$ (Fig. 2). These data are confirmed by Sobel and colleagues who identify these three species as the main cause of candiduria (Sobel et al. 2011).

Azoles, specially FCZ, are by far the most commonly used antifungals in clinical practice and the emergence of the resistance to this chemotherapeutic is a concern in clinical practice (Vandeputte et al. 2012). When assessing the susceptibility profile to $\mathrm{FCZ}$, we observed the resistance phenotype in 32.1\% (29/93) of studied Candida strains (Table II). Our results differ from those obtained by many other studies, which detected a lower incidence of FCZ resistance (Wille et al. 2013, Tortorano et al. 2012, Lockhart et al. 2011, Pfaller et al. 2011, da Matta et al. 2007). These studies evaluated a higher number of samples compared to our study, which focused on a more specific population. This could explain the differences concerning the prevalence of resistance to FCZ. However, our results are consistent with other studies (Puig-Asensio et al. 2014, Tortorano 
et al. 2012) when it comes to emergence of FCZ resistance in strains of Candida tropicalis and Candida glabrata. We observed that the most prevalent FCZ resistant species were C.albicans (11/29), C.tropicalis (13/29), C. glabrata (4/29) and C. krusei (1/29).

The active transport of azoles out of the cell, mediated by membrane $\mathrm{ABC}$ transporters is an important mechanism of resistance in Candida species (Sanglard et al. 2009). Therefore, we decided to evaluate the role of $\mathrm{ABC}$ transporters in the FCZ resistance expressed by the 29 Candida spp. strains. For this, we used the chemosinsitization experiment with FK506 (tacrolimus), a classic inhibitor of Candida ABC transporters (Cannon et al. 2009). We observed that in $75.8 \%$ (22/29) (Fig. 3 ) of these strains, FK506 could reverse the FCZ resistance, revealing a probable contribution of $\mathrm{ABC}$ transporters to this phenotype of resistance. Among the strains chemosensitized by FK506, we identified 11 C.tropicalis, seven C. albicans and four C. glabrata (Table III). Other studies also observed the participation of efflux pumps in FCZ resistance in Candida species. White et al. (2002) assessed the mechanism of resistance in $C$. albicans strains isolated from clinical material and showed that out of 13 strains with a FCZ MIC for $>64 \mu \mathrm{g} / \mathrm{mL}$, six presented overexpression of $\mathrm{ABC}$ transporter genes related to resistance to azoles and CaCdr1/CaCdr2 (White et al. 2002). Evaluating the FCZ resistance mechanism of 20 strains of C. glabrata, Sanguinetti et al. (2005) noted that all FCZ resistant strains showed overexpression of at least one $\mathrm{ABC}$ transporter related to antifungal efflux ( $\mathrm{CgCdr} 1, \mathrm{CgCdr} 2$ and CgSNQ), and that FK506 could chemosensitize all strains (Sanguinetti et al. 2005). Barchiesi et al. (2000) demonstrated that prolonged exposure of C. tropicalis to FCZ induced the expression of an $\mathrm{ABC}$ transporter that promotes the active efflux of this antifungal (Barchiesi et al. 2000). It is worth mentioning that seven of the clinical isolates did not present reversion of resistance phenotype using FK506. This data suggest that probably these strains possess other mechanism of resistance. Besides ABC transporters, Candida species can present an overexpression of major facilitator superfamily (MFS) proteins, another efflux pump that actively extrudes substrates using energy from proton gradient across membrane (Cannon et al. 2009). Additionally, resistance can be developed through different molecular mechanisms concerning: overexpression and/or mutation of ERG11 as well as alterations in ergosterol biosynthetic pathway (Lamping et al. 2010). In order to check and reinforce the possible involvement of $\mathrm{ABC}$ transporters on resistance phenotype, we also performed an efflux assay using R6G. Clinical isolates reverted by FK506 also extruded part of R6G, while the opposite was observed on strains that maintained resistance even in the presence of the inhibitor. These data corroborate the possible involvement of $\mathrm{ABC}$ transporters on resistant profile of those Candida spp. isolates reverted by FK506.

The data obtained so far, reinforce the emergence of FCZ resistant strains of Candida spp. in the hospital environment, as well as the involvement of active drug transporters in resistance phenotype. This phenomenon highlights the need for developing more effective control measures of fungal infections, rational use of antifungal drugs and development of new molecules able to abrogate the active transport of antifungals.

\section{ACKNOWLEDGMENTS}

This work was supported by Conselho Nacional de Desenvolvimento Científico e Tecnológico (CNPq), Fundação Carlos Chagas Filho de Amparo à Pesquisa do Estado do Rio de Janeiro (FAPERJ), Coordenação de Aperfeiçoamento Pessoal de Nível Superior (CAPES), Instituto de Microbiologia Paulo de Góes (IMPG) and Universidade Federal do Rio de Janeiro (UFRJ). The authors thank their lab assistant, Mrs. Geralda Rodrigues Almeida for her great support, Dr. Ana Claudia Tessis (IFRJ - RJ/Brazil) for her help with flow citometry 
experiments and Dr. Louise Kemp for her critical reading of this manuscript.

\section{RESUMO}

A candidíase tem se tornado uma importante preocupação para a prática clínica, especialmente com o aumento da incidência de pacientes imunocomprometidos. Neste cenário, o desenvolvimento da resistência ao fluconazol se apresenta como um desafio ao tratamento dessas infecções oportunistas. O objetivo deste estudo consistiu em avaliar alguns aspectos epidemiológicos das infecções por Candida em um hospital universitário brasileiro, utilizando dados, anteriormente, indisponíveis. Nós observamos que $44 \%$ dos 93 isolados clínicos testados pertenciam à espécie Candida albicans e 56\%, a espécies Candida não-albicans (principalmente Candida tropicalis e Candida glabrata). A maioria das cepas foi isolada de amostras de urina, onde C. albicans foi predominantemente detectada. 29 cepas apresentaram um fenótipo de resistência ao fluconazol e destas, 22 foram quimiosensibilizadas pelo FK506, um inibidor clássico dos transportadores $\mathrm{ABC}$, envolvidos na resistência aos azóis. Estes dados sugerem a provável participação das bombas de efluxo nesse fenótipo de resistência. Nosso estudo ressalta a necessidade do desenvolvimento de medidas de controle efetivas para as infecções fúngicas, o uso racional de antifúngicos e o desenvolvimento de novas moléculas capazes de inibir o transporte ativo de antifúngicos.

Palavras-chave: Candida spp., isolados clínicos, epidemiologia, fluconazol, resistência.

\section{REFERENCES}

Akeme Yamamoto AC, De Paula CR, Dias LB, Tadano T, Martins ER, Amadio JV AND Hahn RC. 2012. Epidemiological and clinical characteristics of nosocomial candidiasis in university hospitals in Cuiaba--Mato Grosso, Brazil. Rev Iberoam Micol 29: 164-168.

Aleva NA, Birman EG, Afonso JR W, Chavasco JK, PaUla CR, Ribeiro A AND PEREIRA LJ. 2007. Erythematous candidosis in patients with complete dentures and HIV+/ AIDS. Mycoses 50: 407-411.

Antunes AG, Pasqualotto AC, Diaz MC, D’Azevedo PA AND SEVERo LC. 2004. Candidemia in a Brazilian tertiary care hospital: species distribution and antifungal susceptibility patterns. Rev Inst Med Trop São Paulo 46: 239-241.
Araújo Paulo de Medeiros M, Vieira de Melo AP, Goncalves SS, Milan EP And Chaves GM. 2014. Genetic relatedness among vaginal and anal isolates of Candida albicans from women with vulvovaginal candidiasis in north-east Brazil. J Med Microbiol 63: 1436-1445.

ARnold HM, MiceK ST, SHORR AF, Zilberberg MD, LABELle AJ, Kothari S AND KolleF MH. 2010. Hospital resource utilization and costs of inappropriate treatment of candidemia. Pharmacotherapy 30: 361-368.

Aubron C, Suzuki S, Glassford NJ, Garcia-Alvarez M, Howden BP AND BELlOMO R. 2015. The epidemiology of bacteriuria and candiduria in critically ill patients. Epidemiol Infect 143(3): 653-662.

Barchiesi F, CAlabrese D, SAnglard D, FAlconi Di Francesco L, CASElli F, Giannini D, Giacometti A, Gavaudan S AND Scalise G. 2000. Experimental induction of fluconazole resistance in Candida tropicalis ATCC 750. Antimicrob Agents Chemother 44: 1578-1584.

CANNON RD, LAmping E, Holmes AR, Nitmi K, BARET PV, KeniYa MV, TanaBe K, NiImI M, GoffeaU A AND MonK BC. 2009. Efflux-mediated antifungal drug resistance. Clin Microbiol Rev 22: 291-332.

Colombo AL, Nucci M, PARK BJ, Nouer SA, ArthingtonSKaGgs B, DA MATTA DA, WARNOCK D AND MORGAN J. 2006. Epidemiology of candidemia in Brazil: a nationwide sentinel surveillance of candidemia in eleven medical centers. J Clin Microbiol 44: 2816-2823.

Colombo AL, Nucci M, Salomao R, Branchini ML, Richtmann R, Derossi A And Wey SB. 1999. High rate of non-albicans candidemia in Brazilian tertiary care hospitals. Diagn Microbiol Infect Dis 34: 281-286.

Colombo AL, Thompson L AND GRAYBILl JR. 2008. The north and south of candidemia: Issues for Latin America. Drugs Today (Barc) 44(Suppl. A): 1-34.

Corzo-Leon DE eT AL. 2014. Surveillance of Candida spp bloodstream infections: epidemiological trends and risk factors of death in two Mexican tertiary care hospitals. PloS One 9: e97325.

Costa SF, MARINHO I, ARAUJo EA, MANRIQUE AE, MEDEIROS EA AND LEVIN AS. 2000. Nosocomial fungaemia: a 2-year prospective study. J Hosp Infect 45: 69-72.

Da Costa VG, Quesada RM, ABE AT, Furlaneto-Maia L AND FURLANETO MC. 2014. Nosocomial bloodstream Candida infections in a tertiary-care hospital in South Brazil: a 4-year survey. Mycopathologia 178: 243-250.

Da Matta DA, De Almeida LP, Machado AM, AzEVEdo aC, Kusano EJ, Travassos NF, Salomao R and COLOMBO AL. 2007. Antifungal susceptibility of 1000 Candida bloodstream isolates to 5 antifungal drugs: results of a multicenter study conducted in São Paulo, Brazil, 1995-2003. Diagn Microbiol Infect Dis 57: 399-404.

De Resende MA, De Sousa LV, De Oliveira RC, KogaITO CY AND LYON JP. 2006. Prevalence and antifungal susceptibility of yeasts obtained from the oral cavity of elderly individuals. Mycopathologia 162: 39-44. 
Egner R, Bauer BE And Kuchler K. 2000. The transmembrane domain 10 of the yeast Pdr5p ABC antifungal efflux pump determines both substrate specificity and inhibitor susceptibility. Mol Microbiol 35: 1255-1263.

Gudlaugsson O, Gillespie S, Lee K, Vande Berg J, Hu J, Messer S, Herwaldt L, Pfaller M and Diekema D. 2003. Attributable mortality of nosocomial candidemia, revisited. Clin Infect Dis 37: 1172-1177.

Hoffmann-Santos HD, Paula CR, Yamamoto AC, TADANO T AND HAHN RC. 2013. Six-year trend analysis of nosocomial candidemia and risk factors in two intensive care hospitals in Mato Grosso, midwest region of Brazil. Mycopathologia 176: 409-415.

KAUFFMAN CA. 2014. Diagnosis and management of fungal urinary tract infection. Infect Dis Clin North Am 28: 61-74.

LAMPING E, BARET PV, Holmes AR, MONK BC, GofFEAU A AND CANNON RD. 2010. Fungal PDR transporters: Phylogeny, topology, motifs and function. Fungal Genet Biol 47: 127-142.

Leite Junior DP, YAmamoto AC, Martins ER, TeiXeIRA AF AND HAHN RC. 2011. Species of Candida isolated from anatomically distinct sites in military personnel in Cuiaba, Mato Grosso, Brazil. An Bras Dermatol 86: 675-680.

Li H, ZHANG C, CHEN Z, SHI W AND Sun S. 2014. A promising approach of overcoming the intrinsic resistance of Candida krusei to fluconazole (FLC)--combining tacrolimus with FLC. FEMS Yeast Res 14: 808-811.

LOCKHART SR ET AL. 2011. Comparison of in vitro susceptibility characteristics of Candida species from cases of invasive candidiasis in solid organ and stem cell transplant recipients: Transplant-Associated Infections Surveillance Network (TRANSNET), 2001 to 2006. J Clin Microbiol 49: 2404-2410.

MAesaKi S, Marichal P, VANDEN Bossche H, SANGLARD D And KoHno S. 1999. Rhodamine 6G efflux for the detection of CDR1-overexpressing azole-resistant Candida albicans strains. J Antimicrob Chemoth 44: 27-31.

MARr KA, SEIDEL K, White TC AND Bowden RA. 2000. Candidemia in allogeneic blood and marrow transplant recipients: evolution of risk factors after the adoption of prophylactic fluconazole. J Infect Dis 181: 309-316.

Mascarenhas RE, Machado MS, Costa e Silva BF, Pimentel RF, FERreira TT, LEONI FM AND Grassi MF. 2012. Prevalence and risk factors for bacterial vaginosis and other vulvovaginitis in a population of sexually active adolescents from Salvador, Bahia, Brazil. Infect Dis Obstet Gynecol 2012: 378640.

Moretti ML, Trabasso P, Lyra L, Fagnani R, Resende Mr, De Oliveira Cardoso LG and Schreiber AZ. 2013. Is the incidence of candidemia caused by Candida glabrata increasing in Brazil? Five-year surveillance of Candida bloodstream infection in a university reference hospital in southeast Brazil. Med Mycol 51: 225-230.
Nascimento MDSB, Leitao VMS, Neto Silva MAC, Maciel LB, Filho Muniz WE, Viana GMC AND BEZERRA GFB. 2014. Eco-epidemiologic study of emerging fungi related to the work of babaçu coconut breakers in the State of Maranhão, Brazil. Rev Soc Bras Med Trop 47: 74-78.

NuCCI M, QueIROZ-Telles F, TOBOn AM, RESTREPO A AND Colombo AL. 2010. Epidemiology of opportunistic fungal infections in Latin America. Clin Infect Dis 51: 561-570.

NUCCI M ET AL. 2013. Recommendations for the management of candidemia in adults in Latin America. Rev Iberoam Micol 30: 179-188.

OLIVEIRA VKP, RUIZ LS, OLIVEIRA NA, MOREIRA D, HAHN RC, Melo AS, Nishikaku AS and Paula CR. 2014. Fungemia caused by Candida species in a children's public hospital in the city of São Paulo, Brazil: study in the period 2007-2010. Rev Inst Med Trop São Paulo 56: 301-305.

PASQUALOTTO AC ET AL. 2008. Take control over your fluconazole prescriptions: the growing importance of Candida glabrata as an agent of candidemia in Brazil. Infect Control Hosp Epidemiol 29: 898-899.

Pfaller MA, ANDEs DR, Diekema DJ, HoRn DL, Reboli AC, Rotstein C, Franks B And AzIE NE. 2014. Epidemiology and outcomes of invasive candidiasis due to non-albicans species of Candida in 2,496 patients: data from the Prospective Antifungal Therapy (PATH) registry 2004-2008. PLoS One 9: e101510.

Pfaller MA, Moet GJ, Messer SA, Jones RN AND CASTANHeIRA M. 2011. Candida bloodstream infections: comparison of species distributions and antifungal resistance patterns in community-onset and nosocomial isolates in the SENTRY Antimicrobial Surveillance Program, 2008-2009. Antimicrob Agents Chemother 55: 561-566.

PRASAD R, PANWAR SL AND SMriti. 2002. Drug resistance in yeasts--an emerging scenario. Adv Microb Physiol 46: 155-201.

PRASAD R AND RAWAL MK. 2014. Efflux pump proteins in antifungal resistance. Front Pharmacol 5: 202.

PUiG-AsEnsio M ET AL. 2014. Epidemiology and predictive factors for early and late mortality in Candida bloodstream infections: a population-based surveillance in Spain. Clin Microbiol Infect 20: 245-254.

Reis de Sa LF, Toledo FT, De Sousa BA, Goncalves AC, Tessis AC, Wendler eP, Comasseto JV, Dos Santos AA AND Ferreira-Pereira A. 2014. Synthetic organotelluride compounds induce the reversal of Pdr5p mediated fluconazole resistance in Saccharomyces cerevisiae. BMC Microbiol 14: 201.

Resende JC, De Resende MA And SAliba JL. 2002. Prevalence of Candida spp. in hospitalized patients and their risk factors. Mycoses 45: 306-312.

Ribeiro AS, Silva DA, Silva FP, SANTos GC, CAmpos LM, OLIVEIRA LV AND SANTOS DA. 2010. Epidemiology and 
phospholipase activity of oral Candida SPP. Among patients with central nervous system diseases before and after dental cleaning procedure. Braz J Microbiol 41: 19-23.

SANGLARD D, Coste A AND Ferrari S. 2009. Antifungal drug resistance mechanisms in fungal pathogens from the perspective of transcriptional gene regulation. FEMS Yeast Res 9: 1029-1050.

SAnguinetTi M, Posteraro B, Fiori B, Ranno S, Torelli R AND FADDA G. 2005. Mechanisms of azole resistance in clinical isolates of Candida glabrata collected during a hospital survey of antifungal resistance. Antimicrob Agents Chemother 49: 668-679.

SANTOLAYA ME ET AL. 2014. Active surveillance of candidemia in children from Latin America: a key requirement for improving disease outcome. Pediatr Infect Dis J 33: e40-44.

Sobel JD, Fisher JF, Kauffman CA AND Newman CA. 2011. Candida urinary tract infections--epidemiology. Clin Infect Dis 52(Suppl. 6): S433-436.

Tortorano AM, Prigitano A, Dho G, Grancini A And PASSERA M. 2012. Antifungal susceptibility profiles of Candida isolates from a prospective survey of invasive fungal infections in Italian intensive care units. J Med Microbiol 61: 389-393.

VANDEPUTTE P, FERRARI S AND COSTE AT. 2012. Antifungal resistance and new strategies to control fungal infections. Int J Microbiol 2012: 26 p.

White TC, Holleman S, Dy F, Mirels LF and Stevens DA. 2002. Resistance mechanisms in clinical isolates of Candida albicans. Antimicrob Agents Chemother 46: 1704-1713.

Wille MP, Guimaraes T, Furtado GH AND Colombo AL. 2013. Historical trends in the epidemiology of candidaemia: analysis of an 11-year period in a tertiary care hospital in Brazil. Mem Inst Oswaldo Cruz 108(3).

Wingard JR, MERZ WG, RinALdi MG, JOHNSON TR, KARP

JE AND SARAL R. 1991. Increase in Candida krusei infection among patients with bone marrow transplantation and neutropenia treated prophylactically with fluconazole. N Engl J Med 325: 1274-1277.

Wisplinghoff H, EbBers J, GeURTZ L, SteFAnIK D, MAJor Y, EDMOND MB, WENZEL RP AND SEIFERT H. 2014. Nosocomial bloodstream infections due to Candida spp. in the USA: species distribution, clinical features and antifungal susceptibilities. Int J Antimicrob Agents 43: 78-81. 